\title{
PENANAMAN NIILAI KARAKTER PADA ANAK USIA DINI MELALUI PEMBELAJARAN BERBASIS MUSIK DAN LAGU MODEL
}

\author{
Setyoadi Purwanto
}

\begin{abstract}
Singing is an activity that can not be separated from the world of education in kindergarten. Every day, students in kindergarten or Raudlatul Athfal there is always a singing activity. Learning atmosphere feels more excited, if students are invited to sing along. It is inevitable that singing is a very effective medium to instill positive characters, such as honest, disciplined, creative, independent, love peace, love reading and love of the homeland. This is in accordance with the concept of edutainment learning, which is an attempt to find common ground educational and entertainment world, especially on the level of $R A$ / TK.
\end{abstract}

Keywords: edutainment learning, educational

\section{A. PENDAHULUAN}

Di tengah-tengah euphoria reformasi yang berlebihan, fenomena perilaku anarkis, pertikaian dan tawuran antarpelajar, antarwarga, antarsekolah, main hakim sendiri, transformasi etika global yang semakin bebas, penyalahgunaan narkoba, serta hubungan antarpribadi yang semakin tidak mengindahkan nilai-nilai etika dan sopan santun menjadi keprihatinan dunia pendidikan kita. Pendidikan sebagai suatu proses humanisasi dan bagian pembangunan watak bangsa belum mampu menanggulangi berbagai krisis demoralisasi dan dehumanisasi yang terjadi saat ini. Pendidikan belum mampu untuk berperan sebagai transfer ilmu pengetahuan (transformation of knowledge) sekaligus sebagai transfer nilai (transformation of value).

Dalam peran sebagai transfer nilai, pendidikan diharapkan mampu 
mentransfer nilai-nilai, norma-norma, dan budi pekerti (akhlakul karimah) yakni proses pembudayaan (enkulturisasi) peserta didik sehingga mereka menjadi warga negara yang memiliki "keadaban" (civility), yang pada gilirannya menjadi pilar bagi pembentukan masyarakat madani, menjadi bangsa yang lebih maju dan beradab. Pembentukan karakter sebagai bagian yang penting dalam proses pendidikan, belum banyak disiapkan secara terencana oleh para pendidik.

Suara kepedulian yang meneriakkan kembali pendidikan karakter, nilai, moral dan budi pekerti serta akhlakul karimah yang dimulai sejak pendidikan usia dini sepertinya harus menjadi perhatian yang serius. Pendidikan di sekolah harus mampu membangkitkan nilai-nilai kehidupan, serta menjelaskan implikasinya terhadap kualitas hidup masyarakat. Lickona menyatakan bahwa sekolah mempunyai dua tujuan utama yakni menfasilitasi peserta didik agar menjadi individu yang cerdas sekaligus baik. $^{1}$

Para pakar yang telah menunjukkan kepeduliannya terhadap kondisi masyarakat Indonesia yang memprihatinkan tersebut dengan cara membenahi sistem pendidikan dan kurikulum dengan menawarkan pendidikan berbasis karakter. Pendidikan berbasis karakter diharapkan mampu menjadi solusi bagi keterpurukan bangsa Indonesia saat ini.

Dalam pembentukan karakter, harus dimulai sejak usia dini, yakni dimulai pada lingkungan keluarga. Sedangkan pada jenjang pendidikan formal yang dikenalkan dalam dunia pendidikan nasional dimulai sejak dari pendidikan di Taman Kanak-Kanak. Jenjang pendidikan Taman Kanak-Kanak/ Raudlatul Athfal merupakan tahap untuk memperkenalkan realitas lingkungan hidup yang lebih luas dibandingkan lingkup keluarga, memperkenalkan realitas hidup bersama yang mempunyai aturan dan nilai hidup. Proses ini dilaksanakan melalui berbagai bentuk kegiatan yang membuat anak senang. Hidup bersama, bersekolah adalah situasi yang menyenangkan dan baik. Itulah yang akan diperkenalkan dan ditanamkan pada jenjang Taman Kanak-Kanak. ${ }^{2}$ Suasana bermain penuh keceriaan, pembiasaan hidup baik dan teratur yang ada pada jenjang taman kanakkanak atau raudlatul athfal perlu didukung dengan berbagai media guna mewujudkan pembelajaran yang humanis dan menggembirakan sesuai

${ }^{1}$ Lickona,T, Educating for Character: How Our School Can Teach Respect and Responsibility (New York: Bantam Books, 1992), hlm.3

${ }^{2}$ Nurul Zuriah, Pendidikan Moral dan Budi Pekerti dalam Perspektif Perubahan: Menggagas Platform Pendidikan Budi Pekerti secara Kontekstual dan Futuristic (Jakarta: Bumi Aksara, 2007), hlm. 41 
dengan konsep pembelajaran berbasis edutainment. Anak-anak harus dikondisikan dan diajak untuk melihat dan mengalami hidup bersama yang baik dan menyenangkan. ${ }^{3}$

Pendidikan karakter di Taman Kanak-Kanak perlu secara sadar dirancang dan dikelola sedemikian rupa, sehingga dalam proses pembelajarannya terjadi pula proses pembentukan sikap dan perilaku yang baik. Menurut Sri Wening, Brooks dan Gooble menyebutkan bahwa dalam menjalankan pendidikan karakter terdapat tiga elemen penting untuk diperhatikanyaitu, prinsip, proses dan praktiknya dalam pembelajaran. Dalam menjalankan prinsip itu nilai-nilai yang diajarkan harus termanifestasikan dalam kurikulum, sehingga semua siswa faham benar tentang nilai-nilai tersebut dan mampu menerjemahkannya dalam perilaku nyata. ${ }^{4}$

Menyanyi merupakan kegiatan yang tidak dapat dipisahkan dari dunia pendidikan di Taman Kanak-Kanak. Setiap hari siswa di Taman Kanak-Kanak ataupun Raudlatul Athfal selalu ada kegiatan bernyanyi. Suasana pembelajaran terasa lebih bersemangat, jika siswa diajak bernyanyi bersama. Tidak dapat dipungkiri bahwa bernyanyi merupakan media yang sangat efektif untuk menanamkan karakter-karakter positif, seperti jujur, disiplin, kreatif, mandiri, cinta damai, gemar membaca dan cinta tanah air. Hal ini sangat sesuai dengan konsep edutainment pembelajaran, yakni upaya menemukan titik kesamaan dunia edukasi dan hiburan khususnya pada jenjang RA/TK.

Sebagai upaya mendukung pelaksanaan pendidikan karakter dapat dilakukan dengan menyiapkan berbagai media, metode, atau model pembelajaran yang tepat. Dunia anak-anak adalah bermain dan bernyanyi, karena dengan bermain dan bernyanyi akan menumbuhkan perasaan senang dan bergairah dalam belajar. Berangkat dari pemikiran di atas, makalah ini mencoba menggali dan mengoptimalkan nilai-nilai edutainment di RA/TK berbasis musik dan lagu model untuk pendidikan karakter.

\section{B. PEMBAHASAN}

\section{Konsep Edutainment dalam Pembelajaran}

Edutaimen adalah sebuah konsep yang dipergunakan dalam dunia pendidikan yang sangat sesuai dengan prinsip pembelajaran anak usia dini,

${ }^{3}$ Ibid, hlm. 46

${ }^{4}$ Sri Wening, Pembentukan Karakter Remaja Awal melalui Pendidikan Nilai yang Terkandung dalam Pendidikan Konsumen: Kajian Evaluasi Reflektif Kurikulum SMP di Yogyakarta, Desertasi Doktor, tidak diterbitkan, Universitas Negeri Yogyakarta, 2007, hlm. 62 
yakni bermain sambil belajar. Edutaimen terdiri dari dua kata yang berbeda yaitu education yang memiliki makna pendidikan, ${ }^{5}$ sementara entertaiment bermakna hiburan, pertunjukan, menyenangkan, ${ }^{6}$. Sebagaimana yang dijelaskan oleh Hamruni dalam bukunya Edutainment dalam Pendidikan Islam dan Teori-Teori Pembelajaran Quantum mendifinisikan bahwa Edutainment adalah proses pembelajaran yang didesain dengan memadukan antara muatan pendidikan dan hiburan secara harmonis sehingga aktivitas pembelajaran dapat berlangsung dengan menyenangkan. ${ }^{7}$

Konsep edutainment pertama kali digunakan di dunia hiburan, oleh The Walt Disney Company. Saat ini edutainment digunakan dan dikembangkan oleh produsen mainan anak, pengelola tempat hiburan, media, dan lembaga pendidikan formal maupun non formal. Makalah ini akan membatasi dan memfokuskan istilah edutainment dalam dunia pendidikan.

\section{Prinsip dan Karakteristik Edutainment}

Ada 4 (empat) prinsip yang sekaligus menjadi karakteristik dari konsep edutainment dalam pembelajaran, antara lain: ${ }^{8}$

a. Menjembatani proses belajar dan proses mengajar

b. Pembelajaran edutainment berlangsung dalam suasana kondusif dan menyenangkan yang didasari 3 asumsi:

1) Perasaan gembira akan mempercepat pembelajaran, sedangkan perasaan negative, seperti terancam, takut, sedih, merasa tidak mampu akan memperlambat belajar bahkan menghentikannya.

2) Jika seseorang menggunakan potensi nalar dan emosinya secara jitu, maka akan menghasilkan lompatan prestasi belajar.

3) Dengan menggunakan metode pembelajaran yang tepat yang mengakomodir gaya dan keunikan belajar siswa, maka belajar akan dapat dioptimalkan.

c. Menempatkan anak sebagai pusat sekaligus subyek pendidikan. Pembelajaran diawali dengan menggali dan memahami kebutuhan anak.

d. Pembelajaran yang lebih humanis.

5 John M. Echols dan Hassan Shadily, An English_Indonesian Dictonary, (Jakarta : PT. Gramedia Pustaka, 1996), hlm. 207.

6 Ibid., hlm. 215.

7 Hamruni, Edutaiment dalam Pendidikan Islam dan Teori-Teori Pembelajaran Quantum (Yogyakarta : Fak. Tarbiyah UIN Sunan Kalijaga, 2009), hlm. 50.

8 Ibid, hlm. 42-45 


\section{Musik dan Lagu Model Pembelajaran}

\section{a. Pengertian Musik dan Lagu Model}

Musik dan lagu adalah bidang keilmuan yang termasuk dalam kelompok seni suara. Pengertian musik banyak dihubungkan dengan bidang seni suara yang mempelajari tentang alat-alat bunyi (instrument), sementara lagu atau nyanyian lebih banyak dihubungkan dengan suara manusia (vokal). Dalam tulisan ini, pengertian musik dan lagu disederhanakan dan dipadukan dengan istilah lagu atau nyanyian. Hal ini dikarenakan kegiatan bermusik anak usia dini (RA/TK) sangat dekat dengan aktivitas menyanyi dan demikian pula sebaliknya.

Sebuah lagu atau nyanyian yang digunakan dalam proses belajar mengajar mempunyai beragam tujuan. Ada pembelajaran yang sengaja ditujukan untuk menguasai lagu sesuai dengan teori musik yang ada. Ketepatan membidik nada, mengintepretasikan tanda-tanda dinamik lagu, artikulasi/vokalisasi lirik lagu secara tepat, dan mengekspresikan jiwa lagu secara total adalah beberapa indicator penilaian lagu dalam pengertian ini. Ada lagu yang digunakan sebagai media pembangun suasana emosi. Lagu yang dinyanyikan untuk mengawali kelas, lagu sisipan/transisi sebagai ice breaker dalam pembelajaran adalah contoh kategori lagu jenis yang satu ini. Dalam kasus-kasus tertentu berlagu dalam pengertian ini sering pula digunakan untuk tujuan-tujuan psikologis seperti trauma healing, seperti penanganan korban bencana alam. Selain fungsi di atas, lagu dalam pembelajaran terkadang digunakan sebagai alat atau media dalam mencapai tujuan kurikulum. Salah satu contohnya adalah lagu model. ${ }^{9}$

Lagu model adalah lagu yang dipilih dan dipergunakan sebagai jembatan dalam mempelajari aspek materi yang diinginkan. Berdasarkan pengertian tersebut, tujuan utama penggunaan lagu model dalam pembelajaran bukanlah penguasaan lagunya, tetapi lagu sebagai alat atau media untuk mempelajari aspek materi yang diinginkan. ${ }^{10}$ Secara khusus lagu model digunakan dalam pembelajaran untuk menyampaikan pesanpesan yang tertuang dalam muatan kurikulum kepada peserta didik. Dengan demikian penekanan inti aspek yang disasar dalam pembelajaran afektif dan psikomotor.

${ }^{9}$ Sugito,Lagu Model sebagai Salah Satu Media Pendidikan yang Efektif Bagi Siswa TKA-TPA di Yogyakarta, Skripsi Fakultas Bahasa dan Seni IKIP Yogyakarta, 1994, hlm. 7

10 Madyo Ekosusilo, Metode Khusus Pengajaran Seni Musik di SD (Semarang: Effhar Offset, 1994), hlm. 19

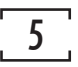




\section{b. Fungsi dan Manfaat Lagu Model}

Lagu model sebagai media penyampai pesan dalam pembelajaran anak usia dini sangatlah efektif. Selain menyenangkan, menyanyi juga telah menjadi bagian yang tak terpisahkan dalam kegiatan pembelajaran anak usia dini, bahkan jauh sebelum itu. Campbel menyatakan, lama sebelum seorang bayi mampu memahami makna setiap patah kata, ia telah terkesan oleh irama dan melodi, kualitas musikal, dalam suara bicara orang-orang sekelilingnya. Jadi musik dan khususnya lagu telah menjadi media belajar alamiah setiap anak manusia. ${ }^{11}$ Fungsi utama penggunaan lagu model dalam pembelajaran adalah mengenalkan dan menyampaikan materi pembelajaran kepada siswa. Jadi bukan aspek penguasaan lagu yang menjadi sasaran utama, namun lagu model sebagai jembatan untuk menguasai materi tertentu. ${ }^{12}$

Adapun manfaat lain penggunaan lagu model dalam pembelajaran antara lain; (1)sarana relaksasi dengan menetralisir denyut jantung dan gelombang otak, (2)menumbuhkan minat dan menguatkan daya tarik pembelajaran, (3)menciptakan proses pembelajaran lebih humanis dan menyenangkan, (4)sebagai jembatan keledai dalam mengingat materi pembelajaran, (5)membangun retensi dan menyentuh emosi dan rasa estetika siswa, (6)proses internalisasi nilai yang terdapat dapat materi pembelajaran, (7)mendorong motivasi belajar siswa. ${ }^{13}$

Beberapa pendapat di atas memberikan gambaran bahwa kaitannya dengan kegiatan pendidikan karakter pada anak usia dini secara tidak langsung lagu model akan menarik minat siswa setidaknya pada keinginan untuk menyimak dan memahami konsep yang bersifat abstrak dalam hal ini berupa nilai-nilai inti dalam pendidikan karakter.

\section{Pendidikan Karakter}

Pendidikan karakter merupakan salah satu tujuan pendidikan nasional. Pasal I UU Sisdiknas tahun 2003 menyatakan bahwa di antara tujuan pendidikan nasional adalah mengembangkan potensi peserta didik untuk memiliki kecerdasan, kepribadian dan akhlak mulia.

11 Don Campbell, Efek Mozart bagi Anak-anak; Meningkatkan daya Pikir, Kseshatan, dan kreativitas Anak Melalui Musik, terj. Alex Tri Kantjono (Jakarta: Gramedia Pustaka Utama, 2001), hlm. 81

12 HT. Silaen. Dkk, Upaya Mengembangkan Pembelajaran Musik melalui Lagu Model bagi Guru-guru di Sekolah Lanjutan Tingkat Pertama di Daerah Istimewa Yogyakarta, Laporan Penelitian Dosen, Fakultas Pendidikan Bahasa dan Seni IKIP Yogyakarta, 1996. Hlm. 7

13 Syamsuri Jari, Reformasi Pendidikan Agama Islam Melalui Musik (Malang: Artisia 6 Press, 2006), hlm. 38-39. 
Karakter adalah satu set tingkah laku atau perilaku dari seseorang yang mana dari perilakunya tersebut, orang lain akan mengenalnya "ia seperti apa". (Kurtus, 1997), senada dengan definisi tersebut, menurut Wynne kata karakter berasal dari bahasa Yunani yang berarti "to mark" (menandai) dan memfokuskan pada aplikasi nilai kebaikan dalam bentuk tingkah laku atau tindakan. ${ }^{14}$ Sedangkan menurut Alwisol karakter diartikan sebagai gambaran tingkah laku yang menonjolkan nilai benar-salah, baikburuk, baik secara eksplisit maupun implisit. ${ }^{15}$ Karakter berbeda dengan kepribadian, karena kepribadian dibebaskan dari nilai. Meskipun demikian, baik kepribadian maupun karakter berwujud pada tingkah laku yang ditunjukkan pada lingkungan sosial. Tindakan atau tingkah laku ataupun sikap yang telah terbentuk melalui pendidikan nilai yang tertanam dalam diri seseorang akan bertahan lama dan sulit berubah, akan tetapi sikap yang belum mendalam pada diri seseorang, akan relatif tidak bertahan lama dan akan mudah berubah.

\section{a. Urgensi Pendidikan Karakter}

Pembentukan karakter merupakan bagian yang penting dalam proses pendidikan suatu bangsa. Pada umumnya setiap lembaga pendidikan berharap agar siswanya berkompeten di bidangnya dan berkarakter baik.

Mengenai cara pembentukan perilaku hingga menjadi karakter, Bimo Walgito mengemukakan tiga cara, yaitu: 1) kondisioning atau pembiasaan, dengan membiasakan diri untuk berperilaku seperti yang diharapkan, akhirnya akan terbentuklah perilaku tersebut; 2) pengertian (insight), cara ini mementingkan pengertian dengan adanya pengertian mengenai perilaku akan terbentuklan perilaku; dan 3) model, dalam hal ini perilaku terbentuk karena adanya model atau teladan yang ditiru. ${ }^{16}$

Dalam penanaman nilai dan pembentukan karakter, suasana bermain, pembiasaan hidup baik dan teratur yang ada pada jenjang taman kanakkanak hendaklah lebih didukung dan semakin dikukuhkan. Anak-anak harus diajak untuk melihat dan mengalami hidup bersama yang baik dan menyenangkan. ${ }^{17}$

14 Wynne,E.A., Character and Academics in The Elementary School. In J.S. Benninga (ed) Moral character, and Civid Education in The Elementary School (New York: Teachers College Press, 1991), hlm.128

15 Alwisol, Psikologi Kepribadian (Malang: UMM, 2006), hlm. 8.

16 Bimo Walgito, Pengantar Psikologi Umum (Yogyakarta: Fakultas Psikologi UGM, 1994), hlm. 79

17 Zuriah, Pendidikan, hlm. 46 


\section{b. Nilai-Nilai dalam Pendidikan Karakter}

Secara imperatif pendidikan karakter bukanlah hal baru dalam sistem pendidikan nasional, karena tujuan pendidikan nasional dalam semua undang-undang yang pernah berlaku, meskipun dengan rumusan yang berbeda secara substantif, semuanya memuat pendidikan karakter. Dalam undang-undang Nomor 20 Tahun 2003 tentang Sistem Pendidikan Nasional, komitmen tentang pendidikan karakter tertuang dalam pasal 3 yang menyatakan bahwa "Pendidikan nasional berfungsi mengembangkan kemampuan dan membentuk watak serta peradaban bangsa yang bermartabat dalam rangka menderdaskan kehidupan bangsa.

Urgensi pengejawantahan komitmen nasional pendidikan karakter, secara kolektif telah dinyatakan pada Sarasehan Nasional Pendidikan Budaya dan Karakter Bangsa sebagai Kesepakatan Nasional Pengembangan Pendidikan Budaya dan Karakter Bangsa (14 Januari 2010). Adapun nilainilai dalam pendidikan budaya dan karakter bangsa yang akan dikembangkan meliputi 18 nilai,

1 Religius

2 Jujur

3 Toleransi

$4 \quad$ Disiplin

5 Kerja Keras

6 Kreatif

$7 \quad$ Mandiri sikap dan perilaku yang patuh dalam melaksanakan ajaran agama yang dianutnya, toleran terhadap pelaksanaan ibadah agama lain, dan hidup rukun dengan pemeluk agama lain).

perilaku yang didasarkan pada upaya menjadikan dirinya sebagai orang yang selalu dapat dipercaya dalam perkataan, tindakan, dan pekerjaan.

Sikap dan tindakan yang menghargai perbedaan agama, suku, etnis, pendapat, sikap, dan tindakan orang lain yang berbeda dari dirinya.

tindakan yang menunjukkan perilaku tertib dan patuh pada berbagai ketentuan dan peraturan.

perilaku yang menunjukkan upaya sungguhsungguh dalam mengatasi berbagai hambatan belajar dan tugas, serta menyelesaikan tugas dengan sebaik-baiknya.

berpikir dan melakukan sesuatu untuk menghasilkan cara atau hasil baru dari sesuatu yang telah dimiliki.

sikap dan perilaku yang tidak mudah tergantung pada orang lain dalam menyelesaikan tugas-tugas. 
8 Demokratis Cara berfikir, bersikap, dan bertindak yang menilai sama hak dan kewajiban dirinya dan orang lain.

9 Rasa Ingin Sikap dan tindakan yang selalu berupaya untuk Tahu mengetahui lebih mendalam dan meluas dari sesuatu yang dipelajarinya, dilihat, dan didengar.

10 Semangat Cara berpikir, bertindak, dan berwawasan yang Kebangsaan menempatkan kepentingan bangsa dan negara di atas kepentingan diri dan kelompoknya.

11 Cinta Tanah Cara berfikir, bersikap, dan berbuat yang Air menunjukkan kesetiaan, kepedulian, dan penghargaan yang tinggi terhadap bahasa, lingkungan fisik, sosial, budaya, ekonomi, dan politik bangsa.

12 Menghargai Sikap dan tindakan yang mendorong dirinya Prestasi untuk menghasilkan sesuatu yang berguna bagi masyarakat, dan mengakui, serta menghormati keberhasilan orang lain.

13 Bersahabat/ Tindakan yang memperlihatkan rasa senang Komunikatif berbicara, bergaul, dan bekerja sama dengan orang lain.

14 Cinta Damai Sikap, perkataan, dan tindakan yang menyebabkan orang lain merasa senang dan aman atas kehadiran dirinya.

15 Gemar Kebiasaan menyediakan waktu untuk membaca Membaca berbagai bacaan yang memberikan kebajikan bagi dirinya.

16 Peduli Sikap dan tindakan yang selalu berupaya mencegah Lingkungan kerusakan pada lingkungan alam di sekitarnya, dan mengembangkan upaya-upaya untuk memperbaiki kerusakan alam yang sudah terjadi.

17 Peduli Sosial Sikap dan tindakan yang selalu ingin memberi bantuan pada orang lain dan masyarakat yang membutuhkan.

18 Tanggung- Sikap dan perilaku seseorang untuk melaksanakan jawab tugas dan kewajibannya, yang seharusnya dia lakukan, terhadap diri sendiri, masyarakat, lingkungan (alam, sosial dan budaya), negara dan Tuhan Yang Maha Esa. 


\section{Mengoptimalkan Nilai-nilai Edutainment Berbasis Musik}

Menggali dan mengoptimalkan nilai-nilai edutainment di TK/RA tidak bisa dilepaskan dari prinsip dasar pembelajaran di TK/RA, yakni bermain sambil belajar. Secara sederhana, prinsip ini bisa dibahasakan "Tak ada belajar tanpa kegiatan yang menyenangkan dan bukan disebut belajar setiap aktivitas yang dilakukan di bawah tekanan, menegangkan, dan membosankan." Salah satu aktivitas bermain yang sangat dominan pada rentang usia ini sepanjang masa adalah bernyanyi. Oleh karenanya, menggali nlai-nilai edutainment di TK/RA tak bisa dipisahkan dari musik dan lagu/ nyanyian.

Menurut Syamsuri Jari ada 3 alasan yang kuat pengembangan dan optimalisasi nilai-nilai edutainment berbasis musik, antara lain ${ }^{18}$ :

a. Suara musik bisa menembus dinding rumah dan hati manusia

b. Penggemar msik lebih banyak bila dibandingkan dengan cabang-cabang kesenian ang lainnya.

c. Musik bisa dinikmati walaupun kita tidak memahami lirik lagunya.

Musik yang diputar di pagi hari oleh Guru piket untuk menyambut kehadiran anak-anak akan member spirit dan motivasi belajar yang menyru dan Murid. Hal ini selaras dengan prinsip edutainment yang pertama, yakni menjembatani proses belajar (Murid) dan proses mengajar (Guru).

Dalam prinsip-prinip edutainment, pembelajaran efektif selalu berlangsung dalam suasana kondusif dan menyenangkan yang didasari 3 asumsi: ${ }^{19}$

a. Perasaan gembira akan mempercepat pembelajaran, sedangkan perasaan negative, seperti terancam, takut, sedih, merasa tidak mampu akan memperlambat belajar bahkan menghentikannya. Musik yang hadir hamper dalam setiap sesi kegiatan di TK/RA akan mengeliminir perasaan negative, seperti terancam, takut, sedih, merasa tidak mampu dan sebaliknya membangun perasaan positif.

b. Jika seseorang menggunakan potensi nalar dan emosinya secara jitu, maka akan menghasilkan lompatan prestasi belajar. Musik memiliki kakuatan luar biasa dalam menyentuh aspek-aspek emosi manusia. Pendidikan karakter berbasis music yang menyenangkan (edutainment) akan mengalirkan dan mengentrainment emosi positif yang pada akhirnya diharapkan akan mengoptimalkan daya nalar sederhana anakanak.

18 Jari, Reformasi , Hlm. 37

19 Hamruni, Edutaiment, hlm. 42-45 
c. Dengan menggunakan metode pembelajaran yang tepat yang mengakomodir gaya dan keunikan belajar siswa, maka belajar akan dapat dioptimalkan. Musik memiliki banyak dimensi yang terkandung dalam unsur-unsurnya, seperti: melodi (rasa estetika), irama (kognisi dan intuisi), harmoni (sosioemosional), dinamika dan tempo (psikomotor). ${ }^{20}$ Unsur- unsur musik yang sangat kompleks ini tentu sangat tepat dan diharapkan mampu mengakomodir gaya dan keunikan belajar siswa.

Karakteristik edutainment lainnya adalah menempatkan anak sebagai pusat sekaligus subyek pendidikan. Musik dan nyanyian memberikan ruang yang sangat besar bagi setiap anak untuk mengekspresikan dan mengaktualisasikan dirinya.

Musik juga melembutkan hati dan menghubungkan sambungrasa antara dua hati manusia. ${ }^{21}$ Pembelajaran berbasis music akan menciptakan pembelajaran yang lebih humanis sebagaimana prinsip edutainment.

\section{Implementasi Pendidikan Karakter Berbasis Musik di RA/TK yang sarat Nilai Edutainment}

Musik dan lagu bagi anak-anak bukanlah semata-mata bahan ajar yang disampaikan untuk mengejar target kurikulum. Musik bukan pula semata-mata media dengar sambilan tanpa makna. Menurut Bagus Takwin sebagaimana diungkapkan Yeni Rachmawati, music tidak saja memberi pengaruh kepada manusia bahkan semesta alam. ${ }^{22}$

Bila didesain dan digunakan secara professional music akan mampu membentuk habit positif berupa pembiasaan-pembiasaan hidup utama dan lebih jauh membangun culture lembaga pendidikan (RA/TK) yang bersangkutan.

Contoh implementasi pendidikan karakter di TK/RA berbasis edutainment dengan pendekatan musikal dapat dijabarkan menurut tema harian berdasarkan target 18 nilai karakter yang dituju, sebagai berikut:

\begin{tabular}{|c|c|l|c|}
\hline \hline NO & HARI & \multicolumn{1}{|c|}{ TEMA } & MUSIK/LAGU TEMA \\
\hline \multirow{3}{*}{1} & Senin & $\begin{array}{l}\text { 1. Disiplin } \\
\text { 2. Semangat Kebangsaan } \\
\text { 3. Cinta Tanah Air }\end{array}$ & $\begin{array}{c}\text { Lagu Wajib Nasional } \\
\text { Lagu Daerah }\end{array}$ \\
\hline
\end{tabular}

20 Yeni Rachmawati, Musik Sebagai Pembentuk Budi Pekerti (Yogyakarta: Panduan Press, 2005), Hlm. xxvii

21 Campbell, Efek, hlm. 27

22 Rachmawati, Musik, Hlm. xvii 


\begin{tabular}{|c|l|l|c|}
\hline 2 & Selasa & $\begin{array}{l}\text { 4. Kerja keras } \\
\text { 5. Mandiri } \\
\text { 6. Menghargai prestasi }\end{array}$ & $\begin{array}{c}\text { Lagu-lagu Motivasi } \\
\text { Instrumen Dinamis }\end{array}$ \\
\hline 3 & Rabu & $\begin{array}{l}\text { 7. Rasa Ingin Tahu } \\
\text { 8. Kreatif } \\
\text { 9. Gema Membaca }\end{array}$ & Lagu Anak Edukatif \\
\hline 4 & Kamis & $\begin{array}{l}\text { 10. Tanggung jawab } \\
\text { 11. Peduli lingkungan } \\
\text { 12. Demokratis }\end{array}$ & Lagu Wajib Nasional \\
\hline 5 & Jum'at & $\begin{array}{l}\text { 13. Religius } \\
\text { 14. Jujur } \\
\text { 15. Peduli Sosial }\end{array}$ & $\begin{array}{r}\text { Lagu Pop Religi } \\
\text { Nasyid/shalawat } \\
\text { Murottal }\end{array}$ \\
\hline 6 & Sabtu & $\begin{array}{l}\text { 16. Toleransi } \\
\text { 17. Bersahabat/komunikatif } \\
\text { 18. Cinta Damai }\end{array}$ & $\begin{array}{r}\text { Lagu Edukatif } \\
\text { Persembahan }\end{array}$ \\
\hline
\end{tabular}

Musik dan lagu tema yang tercantum dalam kolom sebaran mingguan tersebut adalah musik atau lagu yang sengaja dipilih dan ditentukan oleh RA/TA sebagai musik pembuka dalam sesi pesona pagi (sesi penyambutan hangat siswa dan orang tua). Sedang selama sehari hingga pulang sekolah, berbagai lagu model/music lainnya bisa dihadirkan dengan pertimbangan sesuai kebutuhan dan kegiatan. Musik dan lagu tema ini akan menyambut kehadiran setiap siswa yang memasuki lingkungan RA/TK setiap pagi. Musik tema didesain untuk menginspirasi semangat dan membangun tema harian, oleh karenanya perlu dipilih secara cermat agar sesuai dengan target yang dicanangkan. Musik tema harian ini sebaiknya tidak diganti-ganti minimal selama 1 tahun pelajaran ( 2 semester). Hal ini dimaksudkan untuk memberi warna dan membentuk memori bawah sadar guru dan siswa akan target pembelajaran setiap harinya.

Sebagai contoh, hari Senin dipilih lagu Bendera Merah Putih karya Ibu Sud. Lagu ini akan selalu mengingatkan semua sivitas TK/RA (guru, pengelola, siswa, dan orang tua) akan semangat kebangsaan, sikap disiplin, dan cinta tanah air, sekaligus mengingatkan bahwa ini hari Senin. Contoh lain, Lagu Terima Kasih Guruku karya Pak AT. Mahmud dipilih sebagai music/lagu tema hari Sabtu. Selain mengingatkan momentum akhir pekan, lagu ini secara otomatis diharapkan akan mampu mengalirkan semangat persahabatan, toleransi, dan rasa penghargaan atau syukur kepada guru dan 12 orang tua. Tentu saja program sebaran lagu tema harian dalam sepekan ini 
perlu dijabarkan lebih detail dan operasional dalam rencana program harian (RKH).

Musik dan lagu bisa hadir di hampir setiap tahap kegiatan siswa di TK/RA. Sejak pesona pagi (sesi penyambutan dengan lagu tema), 30 menit kegiatan awal, 60 menit kegiatan inti, 30 menit sesi kegiatan bermain bebas, dan bahkan di akhir kegiatan setiap harinya. Selain hadir sebagai lagu tema, musik dan lagu model juga bisa dipilih dan hadir sebagai lagu ilustrasi pengiring kegiatan, lagu background (latar belakang) aktivitas, lagu penyampai pesan dan fungsi-fungsi praktis lainnya. RA/TK tertentu yang telah mencoba mengaplikasikan musik sebagai pendekatan pembelajaran bahkan menggunakan lagu model tertentu untuk memberi tanda-tanda khusus seperti masuk kelas, istirahat, pulang, dan seterusnya.

Sebagai contoh, sebuah TK menggunakan lagu "Taman yang Indah karya Pak AT. Mahmud sebagai kode/tanda istirahat. Maka bila lagu ini diputar, anak-anak dan para guru secara otomatis mengetahui bahwa saat istirahat telah tiba. Di TK yang sama, lagu "Gelang si Paku Gelang" dipilh sebagai penanda waktu pulang sekolah telah tiba. Guru, siswa, dan bahkan orang tua tentu akan segera merespon lagu ini dengan persiapan kegiatan penutupan dan pulang sekolah.

Bentuk kegiatan yang digunakan dalam pembelajaran berbasis musik dalam pendidikan karakter pun beragam, dari sekedar mendengar pasif, mendengar aktif dengan gerakan, menyanyi bersama tanpa iringan, menyanyi bersama dengan iringan musik, menyanyi tunggal, menyanyi dalam permainan, menyanyi dalam upacara, dan berbagai kegiatan menyanyi kreatif lainnya yang direncanakan guru sesuai RKH yang telah disusun.

\section{PENUTUP}

Kegiatan pembelajaran di RA/TK yang berprinsip dasar, bermain sambil belajar semestinya sarat dengan nilai-nilai edutainment. Berlangsung humanis, ringan, ekspresif-impresif, menggembirakan, dan tanpa beban. Praktek-praktek kegiatan di RA/TK yang penuh dengan target kurikulum (seperti calistung yang dipaksakan) tentu betentangan dengan prinsip pembelajaran di TK/RA itu sendiri. Musik dengan berbagai unsur-unsurnya memiliki potensi yang sangat mempesona bila diaplikasikan dalam pembelajaran berbasis edutainment di RA/TK.

Pada umumnya setiap lembaga pendidikan berharap agar siswanya berkompeten di bidangnya dan berkarakter baik. Pembentukan karakter merupakan bagian yang penting dalam proses pendidikan suatu bangsa. 
Pendidikan karakter pada anak usia dini (TK/RA) perlu didesain dengan pendekatan, metode, dan media yang sesuai minat dan kebutuhan anakanak. Dalam banyak kriteria dan sudut pandang, musik memiliki kapasitas terbaik digunakan sebagai media pembelajaran karakter di TK/RA.

Makalah ini tentu masih perlu pengkajian lebih menalam dan ditindaklanjuti dengan upaya penjabaran lebih detail dan operasional sehingga ditemukan model baku pembelajaran berbasis musik di TK/RA yang penuh muatan nilai-nilai edutainment. 


\section{DAFTAR PUSTAKA}

Alwisol, Psikologi Kepribadian (Malang: UMM, 2006)

Bimo Walgito, Pengantar Psikologi Umum (Yogyakarta: Fakultas Psikologi UGM, 1994),

Don Campbell, Efek Mozart bagi Anak-anak; Meningkatkan daya Pikir, Kseshatan, dan kreativitas Anak Melalui Musik, terj. Alex Tri Kantjono (Jakarta: Gramedia Pustaka Utama, 2001)

Hamruni, Edutaiment dalam Pendidikan Islam dan Teori-Teori Pembelajaran Quantum (Yogyakarta : Fak. Tarbiyah UIN Sunan Kalijaga, 2009)

HT. Silaen. Dkk, Upaya Mengembangkan Pembelajaran Musik melalui Lagu Model bagi Guru-guru di Sekolah Lanjutan Tingkat Pertama di Daerah Istimewa Yogyakarta, Laporan Penelitian Dosen, Fakultas Pendidikan Bahasa dan Seni IKIP Yogyakarta, 1996

Lickona,T, Educating for Character: How Our School Can Teach Respect and Responsibility (New York: Bantam Books, 1992)

Madyo Ekosusilo, Metode Khusus Pengajaran Seni Musik di SD (Semarang: Effhar Offset, 1994)

Nurul Zuriah, Pendidikan Moral dan Budi Pekerti dalam PerspektifPerubahan: Menggagas Platform Pendidikan Budi Pekerti secara Kontekstual dan Futuristic (Jakarta: Bumi Aksara, 2007)

Setyoadi Purwanto, Mengembangkan Kreativitas dan Moral Anak melalui

Seni (Yogyakarta: Medika gama Press, 2004)

Sri Wening, Pembentukan Karakter Remaja Awal melalui Pendidikan Nilai yang Terkandung dalam Pendidikan Konsumen: Kajian Evaluasi Reflektif Kurikulum SMP di Yogyakarta, Desertasi Doktor, tidak diterbitkan, Universitas Negeri Yogyakarta, 2007

Sugito,Lagu Model sebagai Salah Satu Media Pendidikan yang Efektif Bagi

Siswa TKA-TPA di Yogyakarta, Makalah, Fakultas Bahasa dan Seni IKIP Yogyakarta, 1994,

Syamsuri Jari, Reformasi Pendidikan Agama Islam Melalui Musik, Malang: Artisia Press, 2006)

Wynne,E.A., Character and Academics in The Elementary School. In J.S. Benninga (ed) Moral character, and Civid Education in The Elementary School (New York: Teachers College Press, 1991)

Yeni Rachmawati, Musik Sebagai Pembentuk Budi Pekerti (Yogyakarta: Panduan Press,2005) 